\title{
ISOLATION AND CHARACTERIZATION OF ENDOPHYTIC BACTERIA ISOLATED FROM THE LEAVES OF THE COMMON BEAN (PHASEOLUS VULGARIS)
}

\section{Leonardo Emanuel de Oliveira Costa; Marisa Vieira de Queiroz*; Arnaldo Chaer Borges; Celia Alencar de Moraes; Elza Fernandes de Araújo}

Universidade Federal de Viçosa, Viçosa, MG, Brasil.

\begin{abstract}
The common bean is one of the most important legumes in the human diet, but little is known about the endophytic bacteria associated with the leaves of this plant. The objective of this study was to characterize the culturable endophytic bacteria of common bean (Phaseolus vulgaris) leaves from three different cultivars (Vermelhinho, Talismã, and Ouro Negro) grown under the same field conditions. The density of endophytic populations varied from $4.5 \times 10^{2}$ to $2.8 \times 10^{3} \mathrm{CFU} \mathrm{g}^{-1}$ of fresh weight. Of the 158 total isolates, $36.7 \%$ belonged to the Proteobacteria, $32.9 \%$ to Firmicutes, $29.7 \%$ to Actinobacteria, and $0.6 \%$ to Bacteroidetes. The three $P$. vulgaris cultivars showed class distribution differences among Actinobacteria, Alphaproteobacteria and Bacilli. Based on 16S rDNA sequences, 23 different genera were isolated comprising bacteria commonly associated with soil and plants. The genera Bacillus, Delftia, Methylobacterium, Microbacterium, Paenibacillus, Staphylococcus and Stenotrophomonas were isolated from all three cultivars. To access and compare the community structure, diversity indices were calculated. The isolates from the Talismã cultivar were less diverse than the isolates derived from the other two cultivars. The results of this work indicate that the cultivar of the plant may contribute to the structure of the endophytic community associated with the common bean. This is the first report of endophytic bacteria from the leaves of $P$. vulgaris cultivars. Future studies will determine the potential application of these isolates in biological control, growth promotion and enzyme production for biotechnology.
\end{abstract}

Key words: Endophytic bacteria, common bean, Phaseolus vulgaris, 16S rDNA, diversity indices.

\section{INTRODUCTION}

The phyllosphere is the habitat for a large diversity of microorganisms. Although bacteria are the predominant microorganisms present in phyllospheres, others such as filamentous fungi are also important members. Phyllosphere bacteria may be found on the surface of plants (epiphytes) as well as in the interior of plant tissues (endophytes) (3, 32, 40). Endophytic bacteria can be defined as those that can be isolated from healthy, superficially disinfected plant tissues and do not cause any damage to the host plant $(15,17)$.

The population density of endophytic bacteria can vary 
from $10^{2}$ to $10^{9}(6,12,25,39,44)$ and depends on many factors, including the plant being studied, the part under analysis $(31,46)$, the developmental stage of the plant $(17,44)$, the plant cultivar (genotype) $(15,44)$ and the interaction with other organisms, as well as other environmental-related factors (17).

The interaction between endophytic bacteria and their host plants is not completely understood. However, many isolates seem to have beneficial effects on their hosts (58). These beneficial effects include promoting host growth and biological control of phytopathogens $(17,21)$.

The common bean (Phaseolus vulgaris) is one of the most important legumes in the human diet and serves as a significant source of proteins (10). The relationship between Rhizobium and other nitrogen-fixing bacteria in the root nodules of beans has been extensively studied (13, 37, 38). Recently, LópezLópez et al. (34) reported the isolation of endophytic bacteria from the seeds and roots of the common bean. However, little is known about endophytic bacteria inhabiting the aerial tissues of the common bean. Therefore, the objective of this study was to isolate the culturable, endophytic bacteria from the leaves of three different common bean cultivars growing in field conditions and characterize the community of culturable bacteria. To our knowledge, this is the first report on endophytic bacteria from the leaves of different cultivars of the common bean.

\section{MATERIALS AND METHODS}

\section{Plant materials}

Samples were collected from three common bean cultivars during the winter of 2007: Talismã (TAL), Ouro Negro (ONG), and Vermelhinho (VER). The cultivars were planted in an experimental field in the town of Coimbra - MG (altitude: 690 m; latitude: $20^{\circ} 45^{\prime} \mathrm{S}$; longitude $42^{\circ} 51^{\prime} \mathrm{W}$ ). During sowing, $350 \mathrm{~kg} \mathrm{ha}{ }^{-1}$ of the 8-28-16 NPK (percentage of nitrogen, phosphorus and potassium) formula was applied, and 25 days after their emergence, the plants were covered in $150 \mathrm{~kg} \mathrm{ha}^{-1}$ of ammonium sulfate. The leaves of the superior portion of the plant (20 cm above the soil) were collected in the vegetative phase 45 days after sowing.

\section{Sample preparation and bacterial isolation}

The collected leaves were washed in running water and those with superficial injury that was visible to the naked eye were excluded. Each isolation procedure was done in triplicate for each cultivar. Each triplicate was composed of approximately 2 g of leaves belonging to two different plants being evaluated, totaling six plants per cultivar. The disinfection and isolation were performed according to Araujo et al. (1) with minor modifications. Briefly, the leaves were disinfected superficially through the following protocol: $70 \%$ alcohol for $1 \mathrm{~min}$, sodium hypochlorite $\left(2.5 \% \mathrm{Cl}^{-}\right)$for $4 \mathrm{~min}$, ethanol for $30 \mathrm{~s}$, and finally 3 rinses in sterile, distilled water. To confirm the disinfection protocol, aliquots of the sterile water used in the final rinse were plated in 10\% TSA $(1.5 \mathrm{~g} / \mathrm{L}$ of triptone, $0.5 \mathrm{~g} / \mathrm{L}$ of soy peptone, $1.5 \mathrm{~g} / \mathrm{L}$ of $\mathrm{NaCl}, 15 \mathrm{~g} / \mathrm{L}$ of agar, $\mathrm{pH} 7.3$ ) at $28{ }^{\circ} \mathrm{C}$ for 15 days and the plates are examined for the presence or absence of microorganismal growth colony.

Initially, the leaves were ground with $6 \mathrm{~mL}$ of aqueous solution $(0.9 \% \mathrm{NaCl})$ using a sterile mortar and pestle. The tissue extract was subsequently incubated at $28{ }^{\circ} \mathrm{C}$ for 3 hours to allow the complete release of endophytic microorganisms from the host tissue. For the isolation of endophytic bacteria, the tissue extract was diluted in an aqueous solution (0.9\% $\mathrm{NaCl}$ ) and plated on five 10\% TSA plates for each dilution $\left(10^{-1}\right.$ and $\left.10^{-2}\right)$. The plates were incubated for up to 15 days at $28^{\circ} \mathrm{C}$. Colonies were selected on days 2, 5, 10, and 15 of incubation and purified in $10 \%$ TSA. For each petri dish evaluated, the colonies were selected according to their time of growth and morphology (color, size, shape). After 15 days of incubation, all of the colonies were counted and expressed as CFU per gram of fresh tissue.

\section{Identification and phylogenetic analysis of endophytic bacteria}

DNA from each isolate was extracted using the following protocol: $1.5 \mathrm{ml}$ of a 48-hour bacterial culture was centrifuged 
for 5 minutes at $14000 \mathrm{~g}$ and resuspended in $1 \mathrm{ml}$ of TE buffer (mM Tris-HCl, 1 mM EDTA, pH 8.0), centrifuged, resuspended in $500 \mu \mathrm{l}$ of TE buffer and finally adding $0.5 \mathrm{~g}$ of glass pearls (0.1 mm in diameter) (Sigma-Aldrich, USA) and $15 \mu \mathrm{l}$ of $20 \%$ SDS. The cells were then homogenized for $30 \mathrm{~s}$ in a vortex mixer (AP56 - Phoenix), $500 \mu \mathrm{l}$ of buffered phenol was added, and the solution was mixed and centrifuged for 5 $\min$ at $14000 \mathrm{~g}$. The aqueous phase was extracted once with phenol-chloroform (1:1) and once more with chloroform. Following the extraction of the aqueous phase, $20 \mu \mathrm{l}$ of $5 \mathrm{M}$ $\mathrm{NaCl}$ was added, the DNA was precipitated with isopropanol (5 min at room temperature) and collected by centrifugation for $10 \mathrm{~min}$ at $14000 \mathrm{~g}$. The DNA pellet was washed with $70 \%$ ethanol, air dried and resuspended in $30 \mu \mathrm{l}$ of autoclaved, ultrapure water.

The amplification of $16 \mathrm{~S}$ rDNA was carried out in a reaction with a final volume of $25 \mu \mathrm{l}$ containing $1 \mu \mathrm{l}$ (0.5-10 ng) of total DNA, $2.5 \mu \mathrm{l}(0.2 \mu \mathrm{M})$ of the P027F primer (5'GAGAGTTTGATCCTGGCTAG-3'), $2.5 \mu \mathrm{l}(0.2 \mu \mathrm{M})$ of the 1378R primer (5’-CGGTGTGTACSSGGCCCGGGAACG-3’), $1.6 \mu \mathrm{l}(200 \mu \mathrm{M})$ of each dNTP, $2.5 \mu \mathrm{l}$ of $5 \mathrm{x}$ IB buffer (Phoneutria; Belo Horizonte, Brazil); $1 \mu l$ (1U) of Taq DNA polymerase (Phoneutria; Belo Horizonte, Brazil), and $2.5 \mu \mathrm{l}$ (25 $\mu$ g) of BSA (Promega). A negative control (PCR mix without DNA) was included in all PCR experiments. The PCR reaction conditions were as follows: $94^{\circ} \mathrm{C}$ for $4 \mathrm{~min}$, followed by 30 cycles of denaturation at $94^{\circ} \mathrm{C}$ for $30 \mathrm{~s}$, annealing at $63^{\circ} \mathrm{C}$ for $1 \mathrm{~min}$ and extension at $72^{\circ} \mathrm{C}$ for $1 \mathrm{~min}$, before a final extension at $72^{\circ} \mathrm{C}$ for $7 \mathrm{~min}$. The PCR products were purified and sequenced by Macrogen Inc. (Seoul, South Korea) using an ABI3730 XL automatic DNA sequencer and the primers P027F and 1378R.

The identification of the isolates was performed using the Ribosomal Database Project (14, 61) and BLAST (http://blast.ncbi.nlm.nih.gov/blast/Blast.cgi) in NCBI. We used the Sequence Match application and BLAST to verify the similarity of experimental sequences with the reference sequences in the databases (14) and classified them at the genus level.

The DNA sequences of 34 reference strains ("type strain”), 2 strains obtained from the Ribosomal Database Project, and 34 representative strains from experimental isolates were aligned using the Ribosomal Database Project. Phylogenetic trees were constructed using the NeighborJoining (NJ) algorithm in $M E G A$ version 4 (56), the Maximum Parsimony (MP) and Maximum Likelihood (ML) algorithm in Paup* (52), and the Bayesian Analysis (BA) algorithm in MrBayes 3.1 (23). The Neighbor Joining method was corrected by the Tamura-Nei multiple base substitution model (55) and by the GAMA distribution (0.4899) established by Modeltest 3.7. The parameters for Maximum Likelihood $(\mathrm{GTR}+\mathrm{I}+\mathrm{G})$ were selected by AIC in Modeltest 3.7 (45). The Bayesian parameters $(\mathrm{GTR}+\mathrm{I}+\mathrm{G})$ were selected by AIC in MrModeltest 2.3 (42). A total of 1000 replications were used for the bootstrap tests of the NJ and MP methods, while the ML test had 100 replications. The $\mathrm{MB}$ was performed in two independent runs with four Markov chain Monte Carlo (MCMC). A total of 10,000,000 generations were run, with trees being sampled every 1000 generations and the first $1,000,000$ trees being discarded. Non-rooted trees were calculated using the 16S rDNA sequence of Methanocaldococcus jannaschii DSM 2661 as an outgroup. The 16S rDNA sequences of each isolate were deposited in the NCBI GENBANK database under the accession numbers HM355592 to HM355749.

\section{Diversity indices}

The diversity indices were calculated in the PAST program version 2.01(20), and the expected number of genotypes in the $\mathrm{R}$ program version 2.11 .1 (47) using the Vegan library (43).

\section{RESULTS}

\section{Endophytic bacteria isolation and identification}

The density of endophytic populations recovered in $10 \%$ 
TSA medium varied from $4.5 \times 10^{2}$ to $2.8 \times 10^{3} \mathrm{CFU} \mathrm{g} \mathrm{g}^{-1}$ per fresh weight. A total of 158 (about $40 \%$ of the total counted) isolates was obtained, of which $31.01 \%$ (49) were isolated from the Talismã cultivar, 37.34\% (59) from the Ouro Negro cultivar and 31.65\% (50) from the Vermelhinho cultivar (Table $1)$.

Table 1. Endophytic isolates obtained from three Phaseolus vulgaris cultivars.

\begin{tabular}{|c|c|c|c|}
\hline \multirow{2}{*}{ Identified taxum } & \multicolumn{3}{|c|}{ Cultivar* } \\
\hline & TAL & ONG & VER \\
\hline Actinobacteria & 25 & 13 & 9 \\
\hline Actinobacteria (class) & 25 & 13 & 9 \\
\hline Agromyces (A. mediolanus; Agromyces sp.) & 0 & 2 & 3 \\
\hline Dietzia (D. cinnamea) & 0 & 0 & 1 \\
\hline Frigoribacterium $(F$. faeni) & 0 & 3 & 0 \\
\hline Kocuria $($ K. palustris $)$ & 1 & 0 & 0 \\
\hline $\begin{array}{l}\text { Microbacterium (M. foliorum; M. phyllosphaerae; Microbacterium } \\
\text { sp.; M. testaceum) }\end{array}$ & 20 & 7 & 5 \\
\hline Micrococcus (M. luteus) & 4 & 0 & 0 \\
\hline Rhodococcus (R. erythropolis) & 0 & 1 & 0 \\
\hline Bacteroidetes & 0 & 0 & 1 \\
\hline Sphingobacteria & 0 & 0 & 1 \\
\hline Sphingobacterium (S. multivorum) & 0 & 0 & 1 \\
\hline Firmicutes & 11 & 23 & 18 \\
\hline Bacilli & 11 & 22 & 18 \\
\hline $\begin{array}{l}\text { Bacillus (B. amyloliquefaciens; B. bataviensis; B. muralis; B. } \\
\text { niacini, Bacillus sp.; B. subtilis; B. thuringiensis) }\end{array}$ & 7 & 3 & 5 \\
\hline Brevibacillus (B. agri) & 0 & 1 & 1 \\
\hline Lysinibacillus (Lysinibacillus sphaericus) & 0 & 0 & 1 \\
\hline Paenibacillus (P. cineris; P. lautus; Paenibacillus sp.) & 1 & 2 & 1 \\
\hline Sporosarcina (S. aquimarina; Sporosarcina sp.) & 0 & 1 & 1 \\
\hline $\begin{array}{l}\text { Staphylococcus (S. caprae; S. epidermidis; S. kloosii; S. } \\
\text { saprophyticus; Staphylococcus sp.; S. warneri;) }\end{array}$ & 3 & 16 & 9 \\
\hline Proteobacteria & 13 & 23 & 22 \\
\hline Alphaproteobacteria & 5 & 14 & 7 \\
\hline Brevundimonas (B. vesicularis) & 1 & 0 & 0 \\
\hline Methylobacterium (M. populi) & 3 & 8 & 7 \\
\hline Rhizobium (R. larrymoorei) & 1 & 4 & 0 \\
\hline Sphingomonas (S. dokdonensis; S. sanguinis) & 0 & 2 & 0 \\
\hline Betaproteobacteria & 1 & 2 & 1 \\
\hline Delftia (D. tsuruhatensis) & 1 & 2 & 1 \\
\hline Gammaproteobacteria & 7 & 7 & 14 \\
\hline Acinetobacter (A. radioresistens; Acinetobacter sp.) & 0 & 0 & 2 \\
\hline Enterobacter (E. asburiae; E. hormaechei) & 4 & 0 & 0 \\
\hline Stenotrophomonas (S. maltophilia; Stenotrophomonas sp.) & 2 & 7 & 10 \\
\hline Pseudomonas (P. aeruginosa) & 1 & 0 & 2 \\
\hline Total & 49 & 59 & 50 \\
\hline
\end{tabular}

* TAL = Talismã; ONG = Ouro Negro; VER = Vermelhinho.

\section{Identification and phylogenetic analyses of endophytic bacteria}

Sequencing of $16 \mathrm{~S}$ rDNA was performed in all 158 isolates. Based on the nucleotide sequences each of the isolates was assigned to 23 different genera (Table 1). In terms of phylum, most isolates belonged to Proteobacteria (36.7\% of the total number of isolates), followed by Firmicutes (32.9\%) and lastly Actinobacteria (29.7\%). Isolates from phylum Bacteroidetes comprised only $0.6 \%$ of the total and only a single isolate was found from the Sphingobacteria 
(Sphingobacteriaceae) of the genus Sphingobacterium. The highest number of isolates belonged to the Bacilli class (32.9\%), comprised of bacteria from the families Staphylococcaceae (17.7\%), Bacillaceae (10.1\%), Paenibacillaceae (3.8\%) and Planococcaceae (1.3\%). The second most prevalent class in isolates was Actinobacteria (29.7\%), which includes Microbacteriaceae (24.7\%), Micrococcaceae (3.1\%), Nocardiaceae (0.6\%) and Dietziaceae (0.6\%). Among the isolates identified as Proteobacteria, the dominant class in the isolate collection was Gammaproteobacteria (17.71\%), with isolates belonging to the families Xanthomonadaceae (12.0\%), Enterobacteriaceae (2.5\%), Pseudomonadaceae (1.9\%) and two (1.3\%) isolates from the family Moraxellaceae. Isolates from the Alphaproteobacteria (16.5\%) comprised representatives from the families Methylobacteriaceae (11.4\%), Rhizobiaceae (3.2\%), Sphingomonadaceae (1.3\%) and one isolate from the family Caulobacteraceae. Betaproteobacteria (2.5\%) contains only members from the family Comamonadaceae (2.5\%).

The relative composition of the bacterial isolates by cultivars is shown in Figure 1 according to class. Differences in the proportions of the classes Actinobacteria, Alphaproteobacteria and Bacilli were observed between the three $P$. vulgaris cultivars. Sphingobacteria were isolated only from the Vermelhinho cultivar, which also exhibited differences in the proportion of isolates belonging to Gammaproteobacteria compared to isolates from the other two cultivars. The proportion of Betaproteobacteria was the same in all cultivars and all isolates of this class belonged to the genus Delftia.

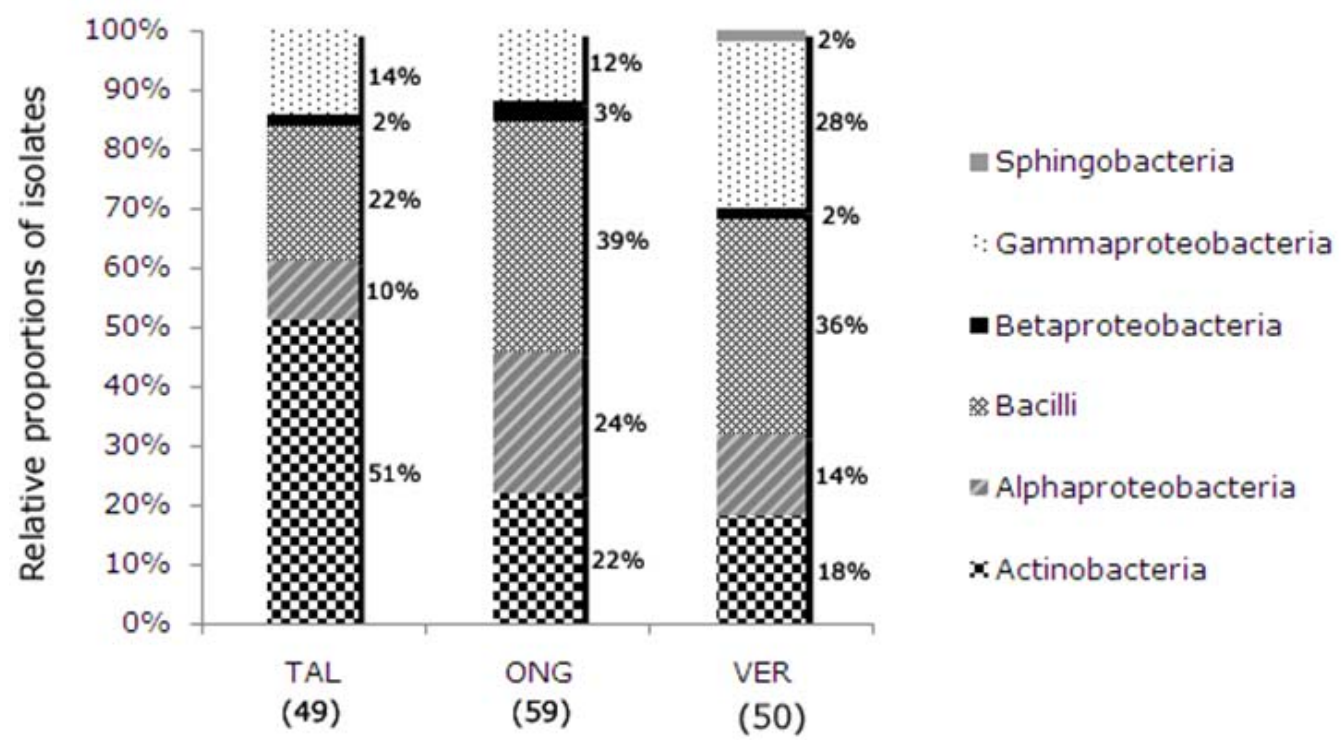

Figure 1. Bacterial class distribution of the culturable endophytic isolates obtained from three Phaseolus vulgaris cultivars: Talismã cultivar (TAL); Ouro Negro cultivar (ONG); Vermelhinho cultivar (VER).

Partial 16S rDNA gene sequences (approximately 1200 bp) from the isolates were used together with sequences taken from the Ribosomal Database Project for construction of phylogenetic trees using four different methods (NeighborJoining, Maximum Parsimony, Maximum Likelihood and Bayesian). The tree obtained by the Bayesian method is shown in Figure 2.

Two major clades were formed with a posterior probability of 0.50 : the first is comprised of Gram positive bacteria and the second of Gram-negative bacteria. The terminal nodes containing isolates BAC2078 and BAC3048 had bootstrap values below 90 as determined by the ML 
method; the terminal node that contained the isolate BAC3114 had bootstrap values below 90 for both the ML and $\mathrm{NJ}$ methods. The terminal node that contained the isolate
BAC2073 had bootstrap values below 90 for the methods MP, ML and NJ. The phylum Bacteroidetes aligned with bacteria from the phylum Proteobacteria.

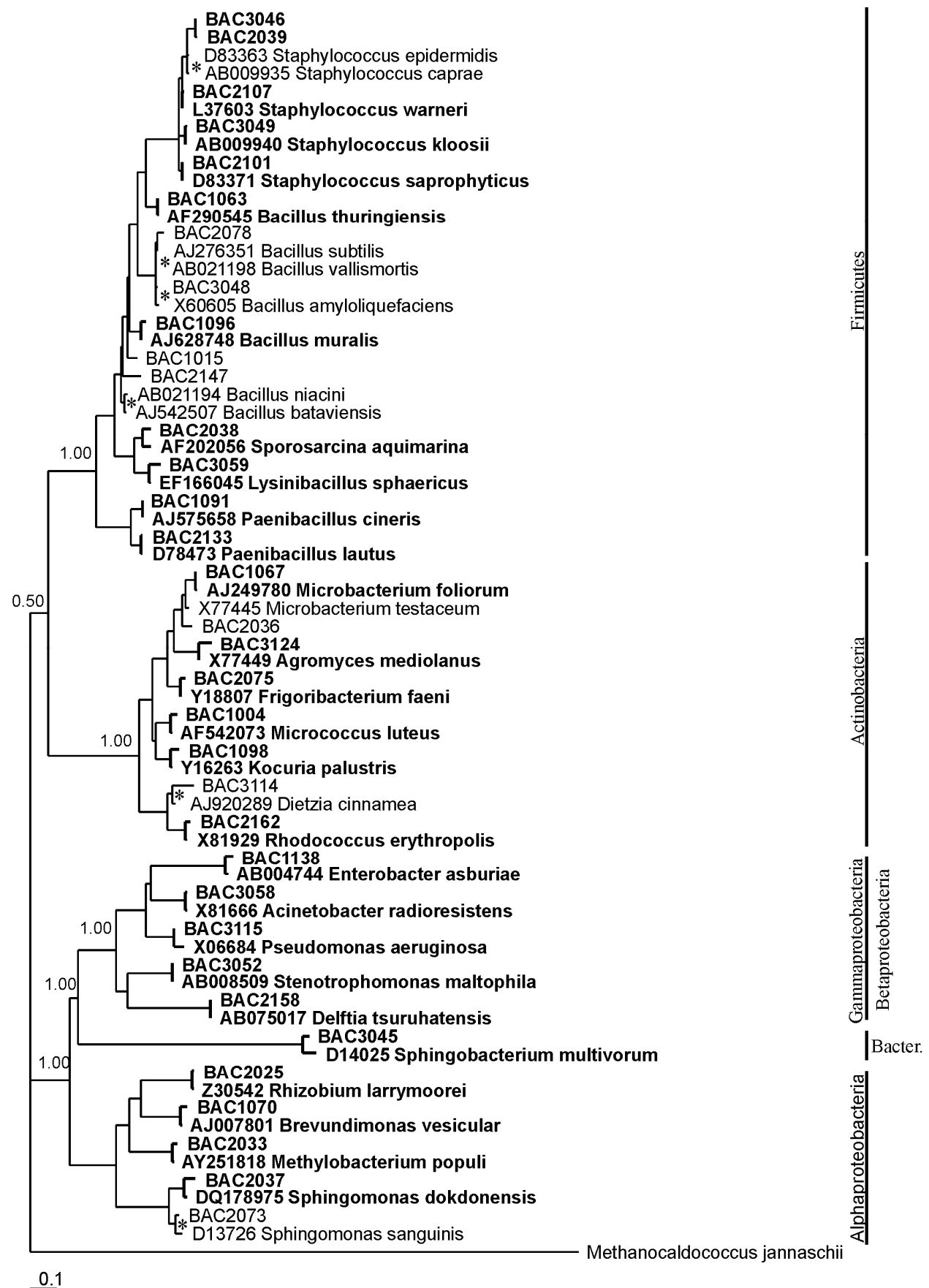

Figure 2. Phylogenetic tree showing the relationship between the $16 \mathrm{~S}$ rDNA gene sequences from representative isolates of endophytic bacteria from three $P$. vulgaris cultivars. Terminal nodes in bold have bootstrap values greater than or equal to 94 in the three methods used (NJ, MP, ML) and presented a posteriori probabilities greater than or equal to 0.99. Terminal nodes with a posteriori probabilities equal to 1.00 and with bootstrap values under 90 in any of the other methods are marked with an *. Bacter. = Bacteroidetes. 


\section{Diversity indices}

The diversity index that was calculated in the PAST program and the expected number of genotypes for each cultivar estimated in the R program can be visualized in Table 2.

Table 2. Number of taxa, individuals, diversity index and expected number of genotypes for each cultivar.

\begin{tabular}{|c|c|c|c|c|}
\hline \multirow{2}{*}{ Diversity indices/Parameters } & \multirow{2}{*}{ Formula $^{\dagger \dagger}$} & \multicolumn{3}{|c|}{ Cultivar } \\
\hline & & TAL & ONG & VER \\
\hline Taxa (S) & - & 13 & 14 & 15 \\
\hline Individuals (n) & - & 49 & 59 & 50 \\
\hline Dominance (D) & $\mathrm{D}=\operatorname{Sum}\left(n_{i} / n\right)^{2}$ & 0.212 & 0.135 & 0.122 \\
\hline Shannon $(\mathrm{H})$ & $\mathrm{H}=\operatorname{Sum}\left(\left(n_{i} / n\right) \ln \left(n_{i} / n\right)\right)$ & 2.002 & 2.282 & 2.340 \\
\hline Simpson (1-D) & $1-\mathrm{D}=1-\operatorname{Sum}\left(n_{i} / n\right)^{2}$ & 0.788 & 0.865 & 0.878 \\
\hline Evenness (E) & $\mathrm{E}=\mathrm{e}^{\mathrm{H}} / \mathrm{S}$ & 0.570 & 0.700 & 0.692 \\
\hline Menhinick (db) & $\mathrm{Db}=\mathrm{S} / \sqrt{n}$ & 1.857 & 1.823 & 2.121 \\
\hline Margalef (Ma) & $\mathrm{Ma}=(S-1) \ln (n)$ & 3.083 & 3.188 & 3.579 \\
\hline Equitability (J) & $\mathrm{J}=\mathrm{H} / \mathrm{Hmax}$ & 0.781 & 0.865 & 0.864 \\
\hline Fisher alpha (FA) & $S=\alpha^{*} \ln (1+n / \alpha)$ & 5.781 & 5.801 & 7.265 \\
\hline Berger-Parker (d) & $\mathrm{d}=\mathrm{n} / \mathrm{nT}$ & 0.408 & 0.271 & 0.200 \\
\hline Expected number of genotypes ${ }^{\dagger}$ & - & 13 & 13.38 & 14.86 \\
\hline
\end{tabular}

$\uparrow$ Calculated in R program version 2.11.1

$\mathrm{t \dagger} \mathrm{n}=$ number of individuals; $\mathrm{ni}=$ number of individuals of taxon $\mathrm{i} ; \mathrm{S}=$ number of taxa; $\mathrm{Nt}=$ number of individuals in the dominant taxon; Hmax = log $\mathrm{S}$.

* Fisher's alpha.

\section{DISCUSSION}

Isolation and identification of endophytic bacteria was performed from the leaves of three common bean ( $P$. vulgaris) cultivars grown under the same field conditions in Minas Gerais during the winter season. The population densities of culturable bacteria in this study were similar to the population density of isolates obtained from soybean leaves growing in herbicide-free soil by Kuklinsky-Sobral et al. (30).

All identified isolates corresponded to genera commonly isolated from either the rhizosphere or bacteria associated with plants. Species from the genera Agromyces, Bacillus, Brevibacillus, Delftia, Dietzia, Enterobacter, Methylobacterium, Microbacterium, Micrococcus, Paenibacillus, Pseudomonas, Rhizobium, Rhodococcus, Sphingobacterium and Stenotrophomonas have already been isolated from rhizospheric soil and as endophytic bacteria in many previous studies (4, 5, 8, 18, 19, 24, 27-30, 36, 48-51, 54, 57-60). Additionally, species from the genera Acinetobacter, Brevundimonas, Frigoribacterium, Kocuria, Sphingomonas, Sporosarcina and Staphylococcus have been isolated or reported in studies of culturable and non-culturable endophytic bacteria (5, 8, 27, 29, 30, 48, 50, 51, 58).

Many of the bacterial genera encountered in this work were previously reported by Lopez-Lopez et al., (34), and many species of genera Bacillus were found by Walker et al. (63) in bean seeds. However, some of the species are not the same. The presence of certain genera in different bean cultivars suggest that they are better adapted to live as endophytic bacteria in $P$. vulgaris than other genera. The genera isolated in this work that have not been previously reported for $P$. vulgaris are as follows: Agromyces, Brevibacillus, Brevundinomonas, Delftia, Dietzia, Frigoribacterium, Lysinibacillus, Sphingobacterium, Sporosarcina and Stenotrophomonas.

Differences in the composition of the endophytic population according to cultivar or clone of plant have been documented for citrus plants, poplar trees, potato, salix and soybean $(2,11,29,41,44,58)$. The results of this study suggest that the cultivar of the plant contributes to the structure of the endophytic community associated with common bean plants or that the observed differences between common bean cultivars could be due to the use of only one sample collected in the Winter of 2007. First, some specific genera were only isolated from a single studied cultivar (Table 1). Second, 
isolate analyses also indicated that the cultivar of the plant may contribute to the determination of associated bacteria. Some of the genera had been isolated with greater frequency from a particular cultivar, for example, the genus Microbacterium from TAL, the genus Staphylococcus from ONG and Stenotrophomonas from VER. The differences between the number and type of isolates in each cultivar may suggest distinct endophytic communities in each cultivar. The differences in diversity of the endophytic communities of the cultivars may also be observed by the comparison of the relative class percentages presented in Figure 1.

To better visualize the community structure of the three common bean cultivars studied, diversity indices (Table 2) were calculated. The diversity indices obtained show that the diversity of bacterial isolates from cultivar Talismã was lower than the diversity of isolates obtained from the other two cultivars while the diversity of bacterial isolates from the cultivar Vermelhinho was the highest. Moreover, the indices Dominance_D and Berger-Parker clearly show that a single taxa of the cultivar Talismã is more abundant in the community, and the number of isolates shown in Table 1 reveal that this is the genus Microbacterium.

Bacteria usually associated with common bean leaf diseases belong to the genera Curtobacterium (22), Pseudomonas (33) and Xanthomonas (62). None of the isolates belong to Curtobacterium or Xanthomonas, while all the isolates belonging to Pseudomonas aligned with different strains of Pseudomonas aeruginosa with scores of 0.999.

The levels of NPK and ammonium sulfate applied to the plants were in accordance with the recommendations for producers in Brazil. However, this high level of nitrogen probably inhibited the nodulation of the bean roots and the association with other nitrogen-fixing bacteria. A few Rhizobium, Pseudomonas, Methylobacterium and Enterobacter species have already been described in the literature as nitrogen-fixing and nodule-forming organisms in the roots of many Leguminosae $(7,26,37,53)$. The five Rhizobium isolates aligned with sequences of Rhizobium larrymoorei, which was originally isolated from tumors affecting aerial parts of Ficus benjamina (9). Some bacterial species considered pathogenic for certain plant species have been isolated as endophytic in other species; from the polar tree, Ulrich et al. (58) isolated endophytes with high similarity to known plant pathogens, such as Clavibacter michiganensis, Pseudomonas syringae and Xanthomonas populi. Maes et. al. (35) also showed that Brenneria salicis could be isolated as an endophyte from poplar (Populus) and alder (Alnus). It is unclear whether these endophytic bacterial species confer some benefit to the host plant or if they merely use the host as a survival strategy in the environment to reach plants on which they can develop disease.

The study of endophytic microorganisms is important to comprehend their interaction with their host plants. Additionally, endophytic microorganisms may have biotechnological applications. The potential of the isolated endophytic bacteria to promote bean plant growth and their biocontrol potential in diseases that affect the aerial parts of this important legume for the human diet will be addressed in future studies.

Table S1. Identity of the 16S rDNA gene sequences of the isolates with the sequences deposited in the database.

\begin{tabular}{|c|c|c|c|c|}
\hline \multirow[b]{2}{*}{ Isolate } & \multicolumn{2}{|r|}{ Ribossomal Database Project } & \multicolumn{2}{|l|}{ NCBI } \\
\hline & $\begin{array}{c}\begin{array}{c}\text { Similarity } \\
\text { score }\end{array} \\
\end{array}$ & Sequence name & Sequence name & $\begin{array}{c}\% \\
\text { identity }\end{array}$ \\
\hline BAC1001 & 1.00 & Bacillus thuringiensis (T); ATCC10792; AF290545 & Bacillus thuringiensis strain ODPY 16S; HM770098.1 & 100 \\
\hline BAC1002 & 1.00 & Micrococcus luteus (T); ATCC 4698; AF542073 & Micrococcus luteus strain EHFS1_S04Ha 16S; EU071593.1 & 100 \\
\hline BAC1003 & 1.00 & Microbacterium testaceum (T); DSM 20166; X77445 & Microbacterium testaceum StLB037; AP012052.1 & 99 \\
\hline BAC1004 & 1.00 & Micrococcus luteus (T); ATCC 4698; AF542073 & Micrococcus luteus strain SV21 16S; GU143803.1 & 99 \\
\hline BAC1005 & 1.00 & Micrococcus luteus (T); ATCC 4698; AF542073 & Micrococcus sp. 185 16S ribosomal RNA gene; EU714334.1 & 99 \\
\hline BAC1006 & 1.00 & Microbacterium testaceum (T); DSM 20166; X77445 & Microbacterium testaceum StLB037; AP012052.1 & 99 \\
\hline BAC1007 & 1.00 & Enterobacter asburiae (T); JCM6051; АB004744 & Enterobacter asburiae strain E53; HQ407230.1 & 99 \\
\hline
\end{tabular}


Table S1. Continuation

\begin{tabular}{|c|c|c|c|c|}
\hline \multirow[b]{2}{*}{ Isolate } & \multicolumn{2}{|r|}{ Ribossomal Database Project } & \multicolumn{2}{|l|}{ NCBI } \\
\hline & $\begin{array}{l}\text { Similarity } \\
\text { score }\end{array}$ & Sequence name & Sequence name & $\begin{array}{c}\% \\
\text { identity }\end{array}$ \\
\hline BAC1008 & 1.00 & Microbacterium testaceum (T); DSM 20166; X77445 & Microbacterium testaceum strain ESS21; EF602568.1 & 99 \\
\hline BAC1009 & 0.98 & Microbacterium testaceum (T); DSM 20166; X77445 & Microbacterium testaceum strain PCSB7 16S; HM449703.1 & 98 \\
\hline BAC1010 & 1.00 & Enterobacter hormaechei (T); CIP 103441; AJ508302 & Enterobacter hormaechei strain Ni-1 16S; HM446004.1 & 99 \\
\hline BAC1011 & 1.00 & Rhizobium larrymoorei $(\mathrm{T}) ; 3-10 ; \mathrm{Z30542}$ & Agrobacterium larrymoorei strain 13638E 16S; EU741094.1 & 100 \\
\hline BAC1012 & 1.00 & $\begin{array}{l}\text { Stenotrophomonas maltophilia }(\mathrm{T}) \text {; ATCC 13637T; } \\
\text { AB008509 }\end{array}$ & Stenotrophomonas maltophilia strain AhsB4 16S; HM143858.1 & 100 \\
\hline BAC1013 & 1.00 & Microbacterium testaceum (T); DSM 20166; X77445 & Microbacterium testaceum StLB037; AP012052.1 & 99 \\
\hline BAC1014 & 1.00 & Microbacterium testaceum (T); DSM 20166; X77445 & Stenotrophomonas maltophilia strain AhsB4 16S; HM143858.1 & 100 \\
\hline BAC1015 & 0.98 & Bacillus niacini (T); IFO15566; АB021194 & Bacillus sp. DL006 16S; GQ355276.1 & 98 \\
\hline BAC1016 & 1.00 & Staphylococcus epidermidis (T); ATCC 14990; D83363 & Staphylococcus epidermidis strain LCR40 16S; FJ976549.1 & 100 \\
\hline BAC1017 & 1.00 & Bacillus thuringiensis (T); ATCC10792; AF290545 & Bacillus thuringiensis strain ODPY 16S; HM770098.1 & 100 \\
\hline BAC1018 & 1.00 & Microbacterium testaceum (T); DSM 20166; X77445 & Microbacterium testaceum StLB037; AP012052.1 & 99 \\
\hline BAC1019 & 1.00 & Microbacterium testaceum (T); DSM 20166; X77445 & Microbacterium testaceum strain ESS21 16S; EF602568.1 & 99 \\
\hline BAC1020 & 1.00 & Microbacterium testaceum (T); DSM 20166; X77445 & Microbacterium testaceum StLB037; AP012052.1 & 99 \\
\hline BAC2021 & 1.00 & Rhizobium larrymoorei (T); 3-10; Z30542 & Agrobacterium larrymoorei strain 13638E 16S; EU741094.1 & 99 \\
\hline BAC2022 & 1.00 & Microbacterium testaceum (T); DSM 20166; X77445 & Microbacterium testaceum StLB037; AP012052.1 & 99 \\
\hline BAC2023 & 0.99 & $\begin{array}{l}\text { Methylobacterium populi (T); BJ001; ATCC BAA-705; } \\
\text { NCIMB 13946; AY251818 }\end{array}$ & Methylobacterium sp. SuP10 16S; EU912450.1 & 100 \\
\hline BAC2024 & 1.00 & $\begin{array}{l}\text { Stenotrophomonas maltophilia (T); ATCC 13637T; } \\
\text { AB008509 }\end{array}$ & Stenotrophomonas maltophilia strain AhsB4 16S; HM143858.1 & 100 \\
\hline BAC2025 & 1.00 & Rhizobium larrymoorei $(\mathrm{T})$; 3-10; Z30542 & Agrobacterium larrymoorei strain 13638E 16S; EU741094.1 & 100 \\
\hline BAC2026 & 1.00 & Staphylococcus epidermidis (T); ATCC 14990; D83363 & Staphylococcus epidermidis strain F71028 16S; HQ908659.1 & 100 \\
\hline BAC2027 & 1.00 & Brevibacillus agri (T); NRRL NRS-1219; D78454 & Brevibacillus agri partial 16S strain R-20121; AJ586388.1 & 99 \\
\hline BAC2028 & 0.99 & $\begin{array}{l}\text { Methylobacterium populi (T); BJ001; ATCC BAA-705; } \\
\text { NCIMB 13946; AY251818 }\end{array}$ & Methylobacterium populi BJ001 16S; CP001029.1 & 99 \\
\hline BAC2029 & 1.00 & Microbacterium testaceum (T); DSM 20166; X77445 & Microbacterium testaceum StLB037; AP012052.1 & 99 \\
\hline BAC2030 & 1.00 & Staphylococcus warneri (T); L37603 & Staphylococcus warneri strain FUA2075 16 S; HQ694734.1 & 99 \\
\hline BAC2031 & 1.00 & $\begin{array}{l}\text { Stenotrophomonas maltophilia (T); ATCC 13637T; } \\
\text { AB008509 }\end{array}$ & Stenotrophomonas maltophilia strain AhsB4 16S; HM143858.1 & 99 \\
\hline BAC2032 & 1.00 & Staphylococcus warneri (T); L37603 & Staphylococcus warneri strain FUA2075 16 S; HQ694734.1 & 99 \\
\hline BAC2033 & 0.99 & $\begin{array}{l}\text { Methylobacterium populi (T); BJ001; ATCC BAA-705; } \\
\text { NCIMB 13946; AY251818 }\end{array}$ & Methylobacterium populi BJ001; CP001029.1 & 99 \\
\hline BAC2034 & 1.00 & Staphylococcus epidermidis (T); ATCC 14990; D83363 & Staphylococcus epidermidis gene for 16S; AB617573.1 & 100 \\
\hline BAC2035 & 1.00 & Staphylococcus epidermidis (T); ATCC 14990; D83363 & Staphylococcus epidermidis strain NM62-4 16S; HM218280.1 & 100 \\
\hline BAC2036 & 0.98 & Microbacterium testaceum (T); DSM 20166; X77445 & Microbacterium hominis strain 1P10AE; EU977655.1 & 99 \\
\hline BAC2037 & 0.98 & Sphingomonas dokdonensis (T); DS-4; DQ178975 & Sphingomonas dokdonensis strain 2P01AE; EU977661.1 & 99 \\
\hline BAC2038 & 0.98 & Sporosarcina aquimarina (T); SW28(T); AF202056 & Sporosarcina luteola gene for 16S; AB473560.1 & 99 \\
\hline BAC2039 & 1.00 & Staphylococcus caprae (T); ATCC 35538T; AB009935 & Staphylococcus capitis strain EHFS2_AU1Hc 16S; EU071603.1 & 100 \\
\hline BAC2040 & 0.99 & $\begin{array}{l}\text { Methylobacterium populi (T); BJ001; ATCC BAA-705; } \\
\text { NCIMB 13946; AY251818 }\end{array}$ & Methylobacterium extorquens AM1; CP001510.1 & 99 \\
\hline BAC3041 & 1.00 & Staphylococcus epidermidis (T); ATCC 14990; D83363 & Staphylococcus epidermidis strain NM62-4 16S; HM218280.1 & 100 \\
\hline BAC3042 & 1.00 & Bacillus thuringiensis (T); ATCC10792; AF290545 & Bacillus thuringiensis serovar colmeri 16S; EU429660.1 & 100 \\
\hline BAC3043 & 1.00 & $\begin{array}{l}\text { Microbacterium foliorum (T); DSM 12966; P 333/02; } \\
\text { AJ249780 }\end{array}$ & Microbacterium foliorum strain 720 16S; EU714376.1 & 99 \\
\hline BAC3044 & 0.97 & $\begin{array}{l}\text { Bacillus bataviensis (T); type strain: LMG 21832; } \\
\text { AJ542507 }\end{array}$ & Bacillus sp. R-30632 partial 16S; AM910246.1 & 99 \\
\hline BAC3045 & 0.98 & Sphingobacterium multivorum (T); IFO 14947; D14025 & Sphingobacterium sp. G-2-27-2 16S; EF102865.1 & 99 \\
\hline BAC3046 & 1.00 & Staphylococcus epidermidis (T); ATCC 14990; D83363 & Staphylococcus epidermidis strain F71028 16S; HQ908659.1 & 100 \\
\hline BAC3047 & 1.00 & Microbacterium testaceum (T); DSM 20166; X77445 & Microbacterium sp. Fek04 16S; EU741023.1 & 99 \\
\hline BAC3048 & 1.00 & Bacillus amyloliquefaciens (T); CR-502; AY603658 & Bacillus amyloliquefaciens LL3; CP002634.1 & 100 \\
\hline ВАС3049 & 1.00 & Staphylococcus kloosii (T); ATCC 43959T; AB009940 & Staphylococcus kloosii strain FR2_36con 16S; EU934080.1 & 100 \\
\hline BAC3050 & 0.99 & $\begin{array}{l}\text { Microbacterium phyllosphaerae (T); DSM 13468; P } \\
\text { 369/06; AJ277840 }\end{array}$ & Microbacterium foliorum strain 720 16S; EU714376.1 & 99 \\
\hline BAC3051 & 0.99 & $\begin{array}{l}\text { Methylobacterium populi (T); BJ001; ATCC BAA-705; } \\
\text { NCIMB 13946; AY251818 }\end{array}$ & Methylobacterium sp. SuP10 16S; EU912450.1 & 99 \\
\hline BAC3052 & 1.00 & $\begin{array}{l}\text { Stenotrophomonas maltophilia (T); ATCC 13637T; } \\
\text { AB008509 }\end{array}$ & Stenotrophomonas maltophilia strain AhsB4 16S; HM143858.1 & 100 \\
\hline
\end{tabular}


Table S1. Continuation

\begin{tabular}{|c|c|c|c|c|}
\hline \multirow[b]{2}{*}{ Isolate } & \multicolumn{2}{|r|}{ Ribossomal Database Project } & \multicolumn{2}{|l|}{ NCBI } \\
\hline & $\begin{array}{c}\text { Similarity } \\
\text { score }\end{array}$ & Sequence name & Sequence name & $\begin{array}{c}\% \\
\text { identity }\end{array}$ \\
\hline BAC3053 & 0.97 & $\begin{array}{l}\text { Bacillus bataviensis (T); type strain: LMG 21832; } \\
\text { AJ542507 }\end{array}$ & Bacillus sp. R-30632 partial 16S; AM910246.1 & 98 \\
\hline BAC3054 & 0.99 & $\begin{array}{l}\text { Methylobacterium populi (T); BJ001; ATCC BAA-705; } \\
\text { NCIMB 13946; AY251818 }\end{array}$ & Methylobacterium sp. SuP10 16S; EU912450.1 & 100 \\
\hline BAC3055 & 0.99 & Staphylococcus warneri (T); L37603 & Staphylococcus warneri strain FUA2075 16S; HQ694734.1 & 98 \\
\hline BAC3056 & 0.92 & Sporosarcina koreensis F73; DQ073393 & Sporosarcina ginsengisoli strain CR5 16S; HQ331532.1 & 90 \\
\hline BAC3057 & 0.82 & Acinetobacter radioresistens INBS1; AM495259 & Acinetobacter radioresistens strain TY37SsD 16S; HQ406757.1 & 81 \\
\hline BAC3058 & 1.00 & Acinetobacter radioresistens (T); DSM 6976; X81666 & Acinetobacter radioresistens strain S13 16S; GU145275.1 & 99 \\
\hline ВАС3059 & 0.98 & Lysinibacillus sphaericus; KNUC228; EF166045 & Lysinibacillus sphaericus strain IMAU80223 16S; GU125639.1 & 97 \\
\hline BAC1061 & 0.92 & Microbacterium testaceum (T); DSM 20166; X77445 & Microbacterium sp. CSBd gene for 16S; AB552874.1 & 91 \\
\hline BAC1062 & 1.00 & Staphylococcus epidermidis (T); ATCC 14990; D83363 & Staphylococcus epidermidis strain NM62-4 16S; HM218280.1 & 100 \\
\hline BAC1063 & 1.00 & Bacillus thuringiensis (T); ATCC10792; AF290545 & Bacillus thuringiensis strain ODPY 16S; HM770098.1 & 100 \\
\hline BAC1064 & 0.99 & $\begin{array}{l}\text { Methylobacterium populi (T); BJ001; ATCC BAA-705; } \\
\text { NCIMB 13946; AY251818 }\end{array}$ & Methylobacterium extorquens DM4 str. DM4; FP103042.2 & 100 \\
\hline BAC1065 & 1.00 & Microbacterium testaceum (T); DSM 20166; X77445 & Microbacterium testaceum strain DSM 20166 16S; NR_026163.1 & 99 \\
\hline BAC1066 & 1.00 & Microbacterium testaceum (T); DSM 20166; X77445 & Microbacterium testaceum StLB037; AP012052.1 & 99 \\
\hline BAC1067 & 1.00 & $\begin{array}{l}\text { Microbacterium foliorum (T); DSM 12966; P 333/02; } \\
\text { AJ249780 }\end{array}$ & Microbacterium foliorum strain 720 16S; EU714376.1 & 99 \\
\hline BAC1068 & 0.99 & $\begin{array}{l}\text { Methylobacterium populi (T); BJ001; ATCC BAA-705; } \\
\text { NCIMB 13946; AY251818 }\end{array}$ & Methylobacterium extorquens AM1; CP001510.1 & 99 \\
\hline BAC1069 & 0.99 & $\begin{array}{l}\text { Methylobacterium populi (T); BJ001; ATCC BAA-705; } \\
\text { NCIMB 13946; AY251818 }\end{array}$ & Methylobacterium extorquens AM1; CP001510.1 & 100 \\
\hline BAC1070 & 0.99 & $\begin{array}{l}\text { Brevundimonas vesicularis (T); ATCC } 11426 \text { (T); } \\
\text { AJ007801 }\end{array}$ & $\begin{array}{l}\text { Brevundimonas vesicularis DNA for } 16 \text { S strain LMG 11141; } \\
\text { AJ227781.1 }\end{array}$ & 99 \\
\hline BAC2071 & 1.00 & Staphylococcus epidermidis (T); ATCC 14990; D83363 & Staphylococcus epidermidis strain LCR40 16S; FJ976549.1 & 100 \\
\hline BAC2072 & 1.00 & Frigoribacterium faeni $(\mathrm{T}) ; 801 ; \mathrm{Y} 18807$ & Frigoribacterium sp. PDD-24b-20 16S; HQ256793.1 & 99 \\
\hline BAC2073 & 0.99 & Sphingomonas sanguinis (T); IFO 13937; D13726 & Sphingomonas pseudosanguinis partial 16S; AM412238.1 & 99 \\
\hline BAC2074 & 0.98 & Staphylococcus warneri $(\mathrm{T}) ; \mathrm{L} 37603$ & Staphylococcus pasteuri partial 16S strain PSM NO.15; FR846535.1 & 98 \\
\hline BAC2075 & 0.99 & Frigoribacterium faeni (T); 801; Y18807 & Frigoribacterium sp. 301 16S; AF157479.1 & 99 \\
\hline BAC2076 & 1.00 & Rhizobium larrymoorei $(\mathrm{T}) ; 3-10 ; \mathrm{Z} 30542$ & Agrobacterium larrymoorei strain 2R46 16S; EF178437.1 & 100 \\
\hline BAC2077 & 1.00 & Staphylococcus epidermidis (T); ATCC 14990; D83363 & Staphylococcus epidermidis strain F71028 16S; HQ908659.1 & 100 \\
\hline BAC2078 & 1.00 & Bacillus subtilis subsp. subtilis (T); DSM10; AJ276351 & Bacillus subtilis strain M-15 16S; HQ401271.1 & 100 \\
\hline BAC2079 & 1.00 & Microbacterium testaceum (T); DSM 20166; X77445 & Microbacterium sp. CSBd gene for 16S; AB552874.1 & 100 \\
\hline BAC2080 & 1.00 & Microbacterium testaceum (T); DSM 20166; X77445 & Microbacterium sp. Fek04 16S; EU741023.1 & 99 \\
\hline BAC3081 & 1.00 & Brevibacillus agri (T); NRRL NRS-1219; D78454 & Brevibacillus agri strain PLIV 16S; HQ166189.1 & 100 \\
\hline BAC3082 & 0.99 & $\begin{array}{l}\text { Methylobacterium populi (T); BJ001; ATCC BAA-705; } \\
\text { NCIMB 13946; AY251818 }\end{array}$ & Methylobacterium sp. SuP10 16S; EU912450.1 & 99 \\
\hline ВАС3083 & 0.99 & $\begin{array}{l}\text { Methylobacterium populi (T); BJ001; ATCC BAA-705; } \\
\text { NCIMB 13946; AY251818 }\end{array}$ & Methylobacterium sp. SuP10 16S; EU912450.1 & 99 \\
\hline BAC3084 & 1.00 & $\begin{array}{l}\text { Paenibacillus cineris (T); type strain:LMG 18439; } \\
\text { AJ575658 }\end{array}$ & Paenibacillus sp. 3492BRRJ 16S; JF309261.1 & 100 \\
\hline BAC3085 & 1.00 & Staphylococcus epidermidis (T); ATCC 14990; D83363 & Staphylococcus epidermidis strain NM62-4 16S; HM218280.1 & 100 \\
\hline BAC3087 & 1.00 & $\begin{array}{l}\text { Microbacterium foliorum (T); DSM 12966; P 333/02; } \\
\text { AJ249780 }\end{array}$ & Microbacterium foliorum strain 720 16S; EU714376.1 & 99 \\
\hline BAC3088 & 0.99 & $\begin{array}{l}\text { Methylobacterium populi (T); BJ001; ATCC BAA-705; } \\
\text { NCIMB 13946; AY251818 }\end{array}$ & Methylobacterium sp. DC2c-19 gene for 16S; AB552870.1 & 99 \\
\hline ВАС3089 & 1.00 & Staphylococcus warneri (T); L37603 & Staphylococcus warneri strain FUA2075 16S; HQ694734.1 & 99 \\
\hline ВАС3090 & 0.99 & $\begin{array}{l}\text { Methylobacterium populi (T); BJ001; ATCC BAA-705; } \\
\text { NCIMB 13946; AY251818 }\end{array}$ & Methylobacterium sp. SuP10 16S; EU912450.1 & 99 \\
\hline BAC1091 & 1.00 & $\begin{array}{l}\text { Paenibacillus cineris (T); type strain:LMG 18439; } \\
\text { AJ575658 }\end{array}$ & Paenibacillus cineris partial 16S; AJ575658.1 & 99 \\
\hline BAC1092 & 1.00 & Microbacterium testaceum (T); DSM 20166; X77445 & Microbacterium testaceum strain 4CAJ3 16S; GQ383916.1 & 99 \\
\hline BAC1093 & 1.00 & Microbacterium testaceum (T); DSM 20166; X77445 & Microbacterium sp. CSBd gene for 16S; AB552874.1 & 99 \\
\hline BAC1094 & 0.99 & $\begin{array}{l}\text { Microbacterium phyllosphaerae (T); DSM 13468; P } \\
\text { 369/06; AJ277840 }\end{array}$ & Microbacterium sp. CSBd gene for 16S & 99 \\
\hline BAC1095 & 1.00 & Micrococcus luteus (T); ATCC 4698; AF542073 & Micrococcus luteus strain EHFS1_S04Ha 16S; EU071593.1 & 100 \\
\hline BAC1096 & 1.00 & Bacillus muralis (T); type strain: LMG 20238; AJ628748 & Bacillus muralis strain REG126 16S; GQ844961.1 & 100 \\
\hline BAC1097 & 0.93 & Microbacterium sp. S15-M4; AM234160 & Microbacterium sp. HY14(2010) 16S; HM579805.1 & 92 \\
\hline
\end{tabular}


Table S1. Continuation

\begin{tabular}{|c|c|c|c|c|}
\hline \multirow[b]{2}{*}{ Isolate } & \multicolumn{2}{|r|}{ Ribossomal Database Project } & \multicolumn{2}{|l|}{ NCBI } \\
\hline & $\begin{array}{c}\text { Similarity } \\
\text { score }\end{array}$ & $\begin{array}{l}\text { Sequence name } \\
\end{array}$ & Sequence name & $\begin{array}{c}\% \\
\text { identity }\end{array}$ \\
\hline BAC1098 & 1.00 & $\begin{array}{l}\text { Kocuria palustris (T); TAGA27 (DSM 11925, type strain); } \\
\text { Y16263 }\end{array}$ & Kocuria palustris strain cT220 16S; JF303036.1 & 99 \\
\hline BAC1099 & 1.00 & Microbacterium testaceum (T); DSM 20166; X77445 & Staphylococcus warneri strain FUA2075 16S; HQ694734.1 & 100 \\
\hline BAC1100 & 1.00 & Microbacterium testaceum (T); DSM 20166; X77445 & Staphylococcus saprophyticus strain OTUC3 16S; FJ210844.1 & 100 \\
\hline BAC2101 & 1.00 & $\begin{array}{l}\text { Staphylococcus saprophyticus subsp. saprophyticus (T); } \\
\text { ATCC } 15305 \text { (= MAFF 911473); D83371 }\end{array}$ & Staphylococcus saprophyticus strain OTUC3 16S; FJ210844.1 & 100 \\
\hline BAC2102 & 1.00 & Staphylococcus warneri (T); L37603 & Staphylococcus warneri strain FUA2075 16S; HQ694734.1 & 100 \\
\hline BAC2103 & 0.99 & $\begin{array}{l}\text { Methylobacterium populi (T); BJ001; ATCC BAA-705; } \\
\text { NCIMB 13946; AY251818 }\end{array}$ & Methylobacterium extorquens gene for 16S rRNA; AB298401.1 & 99 \\
\hline BAC2104 & 1.00 & Delftia tsuruhatensis (T); T7; АB075017 & Delftia tsuruhatensis strain IPPBC R15 16S; HQ436355.1 & 100 \\
\hline BAC2105 & 0.99 & $\begin{array}{l}\text { Methylobacterium populi (T); BJ001; ATCC BAA-705; } \\
\text { NCIMB 13946; AY251818 }\end{array}$ & Methylobacterium extorquens gene for 16S; AB298401.1 & 99 \\
\hline BAC2106 & 0.86 & Bacillus cereus me-5; EU652058 & Bacillus cereus partial 16S; FR749846.1 & 85 \\
\hline BAC2107 & 1.00 & Staphylococcus warneri (T); L37603 & Staphylococcus warneri strain FUA2075 16S; HQ694734.1 & 99 \\
\hline BAC2108 & 0.99 & $\begin{array}{l}\text { Methylobacterium populi (T); BJ001; ATCC BAA-705; } \\
\text { NCIMB 13946; AY251818 }\end{array}$ & Methylobacterium extorquens gene for 16S rRNA; AB298401.1 & 99 \\
\hline BAC2109 & 1.00 & Staphylococcus warneri (T); L37603 & Staphylococcus warneri strain FUA2075 16S; HQ694734.1 & 99 \\
\hline BAC2110 & 1.00 & Frigoribacterium faeni (T); 801; Y18807 & Frigoribacterium faeni partial 16S; AM410686.1 & 99 \\
\hline BAC3111 & 0.99 & Pseudomonas aeruginosa (T); DSM50071; X06684 & Pseudomonas aeruginosa strain CRC5 16S; HQ995502.1 & 100 \\
\hline BAC3112 & 1.00 & Staphylococcus warneri (T); L37603 & Staphylococcus warneri strain FUA2075 16S; HQ694734.1 & 100 \\
\hline BAC3113 & 0.99 & $\begin{array}{l}\text { Methylobacterium populi (T); BJ001; ATCC BAA-705; } \\
\text { NCIMB 13946; AY251818 }\end{array}$ & Methylobacterium chloromethanicum gene for 16S; AB175630.1 & 99 \\
\hline BAC3114 & 0.97 & $\begin{array}{l}\text { Dietzia cinnamea (T); type strain:IMMIB RIV-399; } \\
\text { AJ920289 }\end{array}$ & Dietzia timorensis gene for 16S; AB377289.1 & 100 \\
\hline BAC3115 & 0.99 & Pseudomonas aeruginosa (T); DSM50071; X06684 & Pseudomonas aeruginosa strain MTH8 16S; HQ202541.1 & 100 \\
\hline BAC3116 & 0.95 & Staphylococcus warneri (T); L37603 & Staphylococcus warneri strain FUA2075 16S; HQ694734.1 & 94 \\
\hline BAC3117 & 1.00 & Agromyces mediolanus (T); DSM 20152; X77449 & Agromyces mediolanus gene for 16S; D45054.1 & 99 \\
\hline BAC3118 & 1.00 & Agromyces mediolanus (T); DSM 20152; X77449 & Agromyces mediolanus strain c18 16S; FJ950540.1 & 100 \\
\hline BAC3119 & 1.00 & Staphylococcus warneri (T); L37603 & Staphylococcus warneri strain FUA 3088 16S; GQ222399.1 & 99 \\
\hline BAC3120 & 0.88 & Stenotrophomonas maltophilia; AY484506 & Stenotrophomonas maltophilia strain AhsB4 16S; HM143858.1 & 87 \\
\hline BAC3121 & 1.00 & $\begin{array}{l}\text { Stenotrophomonas maltophilia (T); ATCC 13637T; } \\
\text { AB008509 }\end{array}$ & Stenotrophomonas maltophilia strain AhsB4 16S; HM143858.1 & 100 \\
\hline BAC3122 & 1.00 & $\begin{array}{l}\text { Stenotrophomonas maltophilia (T); ATCC 13637T; } \\
\text { AB008509 }\end{array}$ & Stenotrophomonas maltophilia strain AhsB4; HM143858.1 & 100 \\
\hline BAC3123 & 0.99 & $\begin{array}{l}\text { Stenotrophomonas maltophilia (T); ATCC 13637T; } \\
\text { AB008509 }\end{array}$ & Stenotrophomonas maltophilia strain AhsB4 16S; HM143858.1 & 99 \\
\hline BAC3124 & 0.98 & Agromyces mediolanus (T); DSM 20152; X77449 & Agromyces mediolanus strain c18 16S; FJ950540.1 & 97 \\
\hline BAC3125 & 1.00 & $\begin{array}{l}\text { Stenotrophomonas maltophilia (T); ATCC 13637T; } \\
\text { AB008509 }\end{array}$ & Stenotrophomonas maltophilia strain JKR32b 16S; HQ671069.1 & 100 \\
\hline BAC2126 & 0.99 & Microbacterium testaceum (T); DSM 20166; X77445 & Microbacterium trichotecenolyticum strain 3370 16S; EU714362.1 & 99 \\
\hline BAC2127 & 0.99 & $\begin{array}{l}\text { Stenotrophomonas maltophilia (T); ATCC 13637T; } \\
\text { AB008509 }\end{array}$ & Stenotrophomonas maltophilia strain AhsB4 16S; HM143858.1 & 99 \\
\hline BAC2128 & 1.00 & $\begin{array}{l}\text { Stenotrophomonas maltophilia (T); ATCC 13637T; } \\
\text { AB008509 }\end{array}$ & Stenotrophomonas maltophilia strain AhsB4 16S; HM143858.1 & 100 \\
\hline BAC2129 & 1.00 & Agromyces mediolanus (T); DSM 20152; X77449 & Agromyces mediolanus strain c18 16S; FJ950540.1 & 100 \\
\hline BAC2130 & 0.92 & Agromyces mediolanus DSM 20152; X77449 & Agromyces mediolanus strain c70 16S; FJ950561.1 & 91 \\
\hline BAC2131 & 1.00 & Staphylococcus epidermidis (T); ATCC 14990; D83363 & Staphylococcus epidermidis gene for 16S; AB617573.1 & 100 \\
\hline BAC2132 & 0.99 & $\begin{array}{l}\text { Methylobacterium populi (T); BJ001; ATCC BAA-705; } \\
\text { NCIMB 13946; AY251818 }\end{array}$ & Methylobacterium populi strain TNAU10 16S; EF116588.1 & 98 \\
\hline BAC2133 & 0.99 & Paenibacillus lautus (T); NRRL NRS-666T; D78473 & Paenibacillus lautus strain DS19 16S; EU834247.1 & 99 \\
\hline BAC2134 & 1.00 & $\begin{array}{l}\text { Stenotrophomonas maltophilia (T); ATCC 13637T; } \\
\text { AB008509 }\end{array}$ & Stenotrophomonas maltophilia strain JKR32b 16S; HQ671069.1 & 99 \\
\hline BAC2135 & 1.00 & $\begin{array}{l}\text { Stenotrophomonas maltophilia (T); ATCC 13637T; } \\
\text { AB008509 }\end{array}$ & Stenotrophomonas maltophilia strain AhsB4 16S; HM143858.1 & 100 \\
\hline BAC1136 & 0.99 & $\begin{array}{l}\text { Stenotrophomonas maltophilia (T); ATCC 13637T; } \\
\text { AB008509 }\end{array}$ & Stenotrophomonas maltophilia strain AhsB4 16S; HM143858.1 & 98 \\
\hline BAC1137 & 0.99 & Pseudomonas aeruginosa (T); DSM50071; X06684 & Pseudomonas aeruginosa strain MTH8 16S; HQ202541.1 & 100 \\
\hline BAC1138 & 1.00 & Enterobacter asburiae (T); JCM6051; АB004744 & Enterobacter hormaechei strain Ni-1 16S; HM446004.1 & 99 \\
\hline BAC1139 & 1.00 & Enterobacter hormaechei (T); CIP 103441; AJ508302 & Enterobacter cancerogenus strain M119 16S; HQ407292.1 & 99 \\
\hline
\end{tabular}


Table S1. Continuation

\begin{tabular}{|c|c|c|c|c|}
\hline \multirow[b]{2}{*}{ Isolate } & \multicolumn{2}{|r|}{ Ribossomal Database Project } & \multicolumn{2}{|l|}{ NCBI } \\
\hline & $\begin{array}{c}\text { Similarity } \\
\text { score }\end{array}$ & Sequence name & Sequence name & $\begin{array}{c}\% \\
\text { identity }\end{array}$ \\
\hline BAC1140 & 1.00 & Bacillus thuringiensis (T); ATCC10792; AF290545 & Bacillus thuringiensis strain ODPY 16S; HM770098.1 & 100 \\
\hline BAC1141 & 1.00 & Bacillus thuringiensis (T); ATCC10792; AF290545 & Bacillus thuringiensis strain ODPY 16S; HM770098.1 & 100 \\
\hline BAC2142 & 1.00 & Rhizobium larrymoorei $(\mathrm{T}) ; 3-10 ; \mathrm{Z} 30542$ & Agrobacterium larrymoorei strain 13638E 16S; EU741094.1 & 100 \\
\hline BAC2143 & 0.95 & Staphylococcus warneri $(\mathrm{T}) ; \mathrm{L} 37603$ & Staphylococcus warneri strain FUA2075 16S; HQ694734.1 & 95 \\
\hline BAC2144 & 0.88 & Staphylococcus saprophyticus ATCC 15305; AP008934 & Staphylococcus saprophyticus strain T86 16S; HQ407261.1 & 88 \\
\hline BAC2145 & 0.81 & Paenibacillus lautus JCM 9073; АB073188 & Paenibacillus lactis strain ZYb1 16S; FJ445392.1 & 80 \\
\hline BAC2147 & 0.98 & $\begin{array}{l}\text { Bacillus bataviensis (T); type strain: LMG 21832; } \\
\text { AJ542507 }\end{array}$ & Bacillus circulans strain RIGLD BC1 16S; HQ315829.1 & 98 \\
\hline BAC3148 & 1.00 & $\begin{array}{l}\text { Stenotrophomonas maltophilia }(\mathrm{T}) \text {; ATCC 13637T; } \\
\text { AB008509 }\end{array}$ & Stenotrophomonas sp. 2A9S2 16S; HQ246220.1 & 100 \\
\hline BAC3149 & 1.00 & $\begin{array}{l}\text { Stenotrophomonas maltophilia }(\mathrm{T}) \text {; ATCC 13637T; } \\
\text { AB008509 }\end{array}$ & Stenotrophomonas sp. 2A9N6 16S; HQ246302.1 & 100 \\
\hline BAC3150 & 1.00 & $\begin{array}{l}\text { Stenotrophomonas maltophilia }(\mathrm{T}) \text {; ATCC 13637T; } \\
\text { AB008509 }\end{array}$ & Stenotrophomonas maltophilia strain AhsB4 16S; HM143858.1 & 100 \\
\hline BAC3151 & 1.00 & Bacillus thuringiensis (T); ATCC10792; AF290545 & Bacillus thuringiensis strain NBB6 16S; HQ256544.1 & 100 \\
\hline BAC1152 & 1.00 & Staphylococcus warneri $(\mathrm{T}) ; \mathrm{L} 37603$ & Staphylococcus warneri strain FUA2075 16S; HQ694734.1 & 100 \\
\hline BAC2153 & 1.00 & Microbacterium testaceum (T); DSM 20166; X77445 & Microbacterium testaceum strain BAC2153 16S; HM355741.1 & 100 \\
\hline BAC3154 & 1.00 & Microbacterium testaceum (T); DSM 20166; X77445 & Microbacterium testaceum strain BAC3154 16S; HM355742.1 & 100 \\
\hline BAC3155 & 1.00 & $\begin{array}{l}\text { Stenotrophomonas maltophilia (T); ATCC 13637T; } \\
\text { AB008509 }\end{array}$ & Stenotrophomonas sp. 2A9N6 16S; HQ246302.1 & 100 \\
\hline BAC1156 & 0.92 & Delftia tsuruhatensis (T); T7; АB075017 & Delftia tsuruhatensis strain BN-HKY6 16S; HQ731453.1 & 92 \\
\hline BAC1157 & 1.00 & $\begin{array}{l}\text { Microbacterium foliorum (T); DSM 12966; P 333/02; } \\
\text { AJ249780 }\end{array}$ & Microbacterium foliorum strain DS42 16S; EU834263.1 & 99 \\
\hline BAC2158 & 1.00 & Delftia tsuruhatensis (T); T7; АB075017 & Delftia tsuruhatensis strain BN-HKY6 16S; HQ731453.1 & 100 \\
\hline BAC3159 & 1.00 & Delftia tsuruhatensis (T); T7; АB075017 & Delftia tsuruhatensis strain BN-HKY6 16S; HQ731453.1 & 100 \\
\hline BAC2160 & 1.00 & $\begin{array}{l}\text { Stenotrophomonas maltophilia (T); ATCC 13637T; } \\
\text { AB008509 }\end{array}$ & Stenotrophomonas maltophilia strain BAC3148 16S; HM355736.1 & 100 \\
\hline BAC2162 & 1.00 & Rhodococcus erythropolis (T); ATCC 4277T; X81929 & Rhodococcus erythropolis strain BAC2162 16S; HM355749.1 & 100 \\
\hline
\end{tabular}

\section{ACKNOWLEDGEMENTS}

We would like to thank the Brazilian institutions CAPES (Coordenação de Aperfeiçoamento de Pessoal de Nível Superior), CNPq (Conselho Nacional de Desenvolvimento Científico e Tecnológico) and FAPEMIG (Fundação de Amparo à Pesquisa do Estado de Minas Gerais) for financial support.

\section{REFERENCES}

1. Araújo, W. L.; Lima, A.O.S.; Azevedo, J.L.; Marcon, J.; KuklinskySobral, J.; Lacava, P.T. (2002) Manual: Isolamento de microrganismos endofíticos. Departamento de Genética Escola Superior de Agricultura “Luiz de Queiroz” - Universidade de São Paulo, Piracicaba, SP.

2. Araujo, W.L.; Marcon, J.; Maccheroni, W.Jr.; van Elsas, J.D.; van Vuurde, J.W.L.; Azevedo, J.L. (2002). Diversity of endophytic bacterial populations and their interaction with Xylella fastidiosa in citrus plants. Appl. Environ. Microbiol. 68(10): 4906-4914.
3. Arnold, A.E.; Maynard, Z.; Gilbert, G.S.; Coley, P.D.; Kursar, T.A. (2000). Are tropical fungal endophytes hyperdiverse? Ecol. Lett. 3(4): 267-274.

4. Azanza, M.; Azanza, R.; Vargas, V.; Hedreyda, C. (2006). Bacterial endosymbionts of Pyrodinium bahamense var. compressum. Microb. Ecol. 52(4): 756-764.

5. Barzanti, R.; Ozino, F.; Bazzicalupo, M.; Gabbrielli, R.; Galardi, F.; Gonnelli, C.; Mengoni, A. (2007). Isolation and characterization of endophytic bacteria from the nickel hyperaccumulator plant Alyssum bertolonii. Microb. Ecol. 53(2): 306-316.

6. Bell, C.R.; Dickie, G.A.; Harvey, W.L.G.; Chan, J. (1995). Endophytic bacteria in grapevine. Can. J. Microbiol. 41(1): 46-53.

7. Benhizia, Y.; Benhizia, H.; Benguedouar, A.; Muresu, R.; Giacomini, A.; Squartini, A. (2004). gamma proteobacteria can nodulate legumes of the genus Hedysarum. Syst. Appl. Microbiol. 27(4): 462-468.

8. Berg, G.; Krechel, A.; Ditz, M.; Sikora, R.A.; Ulrich, A.; Hallmann, J. (2005). Endophytic and ectophytic potato-associated bacterial communities differ in structure and antagonistic function against plant pathogenic fungi. FEMS Microbiol. Ecol. 51(2): 215-229.

9. Bouzar, H.; Jones, J. (2001). Agrobacterium larrymoorei sp. nov., a pathogen isolated from aerial tumours of Ficus benjamina. Int. J. Syst. Evol. Microbiol. 51(3): 1023-1026. 
10. Broughton, W.J.; Hernández, G.; Blair, M.; Beebe, S.; Gepts, P.; Vanderleyden, J. (2003). Beans (Phaseolus spp.) - model food legumes. Plant Soil 252(1): 55-128.

11. Cambours, M.A.; Nejad, P.; Granhall, U.; Ramstedt, M. (2005). Frostrelated dieback of willows. Comparison of epiphytically and endophytically isolated bacteria from different Salix clones, with emphasis on ice nucleation activity, pathogenic properties and seasonal variation. Biomass Bioenergy 28(1): 15-27.

12. Chi, F.; Shen, S.-H.; Cheng, H.P.; Jing, Y.X.; Yanni, Y.G.; Dazzo, F.B. (2005). Ascending migration of endophytic rhizobia, from roots to leaves, inside Rice plants and assessment of benefits to rice growth physiology. Appl. Environ. Microbiol. 71(11): 7271-7278.

13. Cocking, E.C. (2003). Endophytic colonization of plant roots by nitrogen-fixing bacteria. Plant Soil 252(1): 169-175.

14. Cole, J.R.; Wang, Q.; Cardenas, E.; Fish, J.; Chai, B.; Farris, R.J.; Kulam-Syed-Mohideen, A.S.; McGarrell, D.M.; Marsh, T.; Garrity, G.M.; Tiedje, J.M. (2009). The Ribosomal Database Project: improved alignments and new tools for rRNA analysis. Nucleic Acids Res. 37(S1): D141-145.

15. Compant, S., Duffy, B., Nowak, J., Clement, C., Barka, E.A. (2005). Use of Plant Growth-Promoting Bacteria for Biocontrol of Plant Diseases: Principles, Mechanisms of Action, and Future Prospects. Appl. Environ. Microbiol. 71 (9): 4951-4959.

16. Fromin, N.; Achouak, W.; Thiéry, J.M.; Heulin, T. (2001). The genotypic diversity of Pseudomonas brassicacearum populations isolated from roots of Arabidopsis thaliana: influence of plant genotype. FEMS Microbiol. Ecol. 37(1): 21-29.

17. Hallmann, J.; QuadtHallmann, A.; Mahaffee, W.F.; Kloepper, J.W. (1997). Bacterial endophytes in agricultural crops. Can. J. Microbiol. 43(10): 895-914.

18. Hallmann, J.; Rodríguez-Kábana, R.; Kloepper, J.W. (1999). Chitinmediated changes in bacterial communities of the soil, rhizosphere and within roots of cotton in relation to nematode control. Soil Biol. Biochem. 31(4): 551-560.

19. Han, J.; Xia, D.; Li, L.; Sun, L.; Yang, K.; Zhang, L. (2009). Diversity of culturable bacteria isolated from root domains of Moso Bamboo (Phyllostachys edulis). Microb Ecol 58, 363-373.

20. Hammer, Ø.; Harper, D.A.T.; Ryan, P.D. (2001). PAST: Paleontological statistics software package for education and data analysis. Palaeontol. Electronica 4(1), 1-9. http://palaeo-electronica.org/2001_1/past/ issue1 01.htm.

21. Hardoim, P.R.; van Overbeek, L.S.; and Elsas, J.D.v. (2008). Properties of bacterial endophytes and their proposed role in plant growth. Trends Microbiol. 16: 463-471.

22. Hedges, F. (1922). A bacterial wilt of the bean caused by Bacterium flaccumfaciens nov. sp. Science 55(1425): 433-434.

23. Huelsenbeck, J.P.; Ronquist, F. (2001). MRBAYES: Bayesian inference of phylogenetic trees. Bioinformatics 17(8): 754-755.

24. Idris, R.; Trifonova, R.; Puschenreiter, M.; Wenzel, W.; Sessitsch, A. (2004). Bacterial communities associated with flowering plants of the $\mathrm{Ni}$ hyperaccumulator Thlaspi goesingense. Appl. and Environ. Microbiol. 70(5): 2667-2677.

25. Jacobs, M.J.; Bugbee, W.M.; Gabrielson, D.A. (1985). Enumeration, location, and characterization of endophytic bacteria within sugar-beet roots. Can. J. Bot. 63(7): 1262-1265.

26. Jourand, P.; Giraud, E.; Bena, G.; Sy, A.; Willems, A.; Gillis, M. Dreyfus, B.; Lajudie, P. (2004). Methylobacterium nodulans sp. nov., for a group of aerobic, facultatively methylotrophic, legume root-noduleforming and nitrogen-fixing bacteria. Int. J. Syst. Evol. Microbiol. 54(6): 2269-2273.

27. Kang, S.; Cho, H.; Cheong, H.; Ryu, C.; Kim, J.; Park, S. (2007). Two bacterial entophytes eliciting both plant growth promotion and plant defense on pepper (Capsicum annuum L.). J. Microbiol. Biotechnol. 17(1): 96-103.

28. Kuffner, M.; Puschenreiter, M.; Wieshammer, G.; Gorfer, M.; Sessitsch, A. (2008). Rhizosphere bacteria affect growth and metal uptake of heavy metal accumulating willows. Plant Soil 304(1): 35-44.

29. Kuklinsky-Sobral, J.; Araújo, W.L.; Mendes, R.; Geraldi, I.O.; PizziraniKleiner, A.A.; Azevedo, J.L. (2004). Isolation and characterization of soybean-associated bacteria and their potential for plant growth promotion. Environ. Microbiol. 6(11): 1244-1251.

30. Kuklinsky-Sobral, J.; Araújo, W.L.; Mendes, R.; Pizzirani-Kleiner, A.A.; Azevedo, J.L. 2005. Isolation and characterization of endophytic bacteria from soybean (Glycine max) grown in soil treated with glyphosate herbicide. Plant Soil 273(1): 91-99.

31. Lamb, T.G.; Tonkyn, D.W.; Kluepfel, D.A. (1996). Movement of Pseudomonas aureofaciens from the rhizosphere to aerial plant tissue. Can. J. Microbiol. 42(11): 1112-1120.

32. Lindow, S.E.; Brandl, M.T. (2003). Microbiology of the phyllosphere. Appl. Environ. Microbiol. 69(4): 1875-1883.

33. Lindow, S.E.; Arny, D.C.; Upper, C.D. (1978). Distribution of ice nucleation-active bacteria on plants in nature. Appl. Environ. Microbiol. 36(6): 831-838.

34. López-López A., Rogel, M.A.; Ormeño-Orrillo, E.; Martínez-Romero, J.; Martínez-Romero, E. (2010). Phaseolus vulgaris seed-borne endophytic community with novel bacterial species such as Rhizobium endophyticum sp. nov. Syst. Appl. Microbiol. 33, 322-327

35. Maes, M.; Huvenne, H.; Messens, E. (2009). Brenneria salicis, the bacterium causing watermark disease in willow, resides as an endophyte in wood. Environ Microbiol 11, 1453-1462.

36. Mano, H.; Tanaka, F.; Nakamura, C.; Kaga, H.; Morisaki, H. (2007). Culturable endophytic bacterial flora of the maturing leaves and roots of rice plants (Oryza sativa) cultivated in a paddy field. Microb Environ 22, 175-185. 
37. Martínez-Romero, E. (2003). Diversity of Rhizobium-Phaseolus vulgaris symbiosis: overview and perspectives. Plant Soil 252(1): 11-23.

38. Martínez-Romero, E. (2009). Coevolution in Rhizobium-legume symbiosis? DNA Cell Biol. 28(8): 361-370.

39. Misaghi, I.J.; Donndelinger, C.R. (1990). Endophytic bacteria in symptom-free cotton plants. Phytopathology 80(9): 808-811.

40. Monier, J.-M.; Lindow, S.E. (2004). Frequency, size, and localization of bacterial aggregates on bean leaf surfaces. Appl. Environ. Microbiol. 70(1): 346-355.

41. Moore, F.P.; Barac, T.; Borremans, B.; Oeyen, L.; Vangronsveld, J.; van der Lelie, D.; Campbell, C.D.; Moore, E.R.B. (2006). Endophytic bacterial diversity in poplar trees growing on a BTEX-contaminated site: the characterization of isolates with potential to enhance phytoremediation. Syst. Appl. Microbiol. 29(7): 539-556.

42. Nylander, J.A.A. (2004). MrModeltest 2.3. Program distributed by the author. In: Evolutionary Biology Centre, Uppsala University.

43. Oksanen, J.; Blanchet, F.G.; Kindt, R.; Legendre, P.; O'Hara, R.B.; Simpson, G.L.; Solymos, P.; Stevens, M.H.H.; Wagner. H. (2010). vegan: Community Ecology Package. $\mathrm{R}$ package version 1.17-3. http://CRAN.R-project.org/package=vegan

44. Overbeek, L.v.; Elsas, J.D.v. (2008). Effects of plant genotype and growth stage on the structure of bacterial communities associated with potato (Solanum tuberosum L.). FEMS Microbiol. Ecol. 64(2): 283-296.

45. Posada, D.; Crandall, K. (1998). MODELTEST: testing the model of DNA substitution. Bioinformatics 14(9): 817-818.

46. QuadtHallmann, A.; Kloepper, J.W. (1996). Immunological detection and localization of the cotton endophyte Enterobacter asburiae JM22 in different plant species. Can. J. Microbiol. 42(11): 1144-1154.

47. 47. R Development Core Team 2010. R: A language and environment for statistical computing. R Foundation for Statistical Computing, Vienna, Austria. ISBN 3-900051-07-0, Available at: http://www.Rproject.org. Accesed 08 February 2011.

48. Rijavec, T.; Lapanje, A.; Dermastia, M.; Rupnik, M. (2007). Isolation of bacterial endophytes from germinated maize kernels. Can. J. Microbiol. 53(6): 802-808.

49. Rivas, R.; Trujillo, M.; Mateos, P.; Martinez-Molina, E.; Velaquez, E. (2004). Agromyces ulmi sp nov., a xylanolytic bacterium isolated from Ulmus nigra in Spain. Int. J. Syst. Evol. Microbiol. 54(6): 1987-1990.

50. Sun, L.; Qiu, F.; Zhang, X.; Dai, X.; Dong, X.; Song, W. (2008). Endophytic bacterial diversity in rice (Oryza sativa L.) roots estimated by 16S rDNA Sequence Analysis. Microb. Ecol. 55(3): 415-424.

51. Surette, M.; Sturz, A.; Lada, R.; Nowak, J. (2003). Bacterial endophytes in processing carrots (Daucus carota L. var. sativus): their localization, population density, biodiversity and their effects on plant growth. Plant Soil 253(2): 381-390.

52. Swofford, D.L. (2003). PAUP*. Phylogenetic analysis using parsimony (*and other methods). In. Sunderland, Massachusetts.: Sinauer Associates.

53. Sy, A.; Giraud, E.; Jourand, P.; Garcia, N.; Willems, A.; de Lajudie, P.; Prin, Y.; Neyra, M.; Gillis, M.; Boivin-Masson, C.; Dreyfus, B. (2001). Methylotrophic Methylobacterium bacteria nodulate and fix nitrogen in symbiosis with legumes. J. Bacteriol. 183(1): 214-220.

54. Takeuchi, M.; Hatano, K. (2001). Agromyces luteolus sp nov., Agromyces rhizospherae sp nov and Agromyces bracchium sp nov., from the mangrove rhizosphere Int. J. Syst. Evol. Microbiol. 51(4): 15291537.

55. Tamura, K.; Nei, M. (1993). Estimation of the number of nucleotide substitutions in the control region of mitochondrial DNA in humans and chimpanzees. Mol. Biol. Evol. 10(3): 512-526.

56. Tamura, K.; Dudley, J.; Nei, M.; Kumar, S. (2007). MEGA4: Molecular evolutionary genetics analysis (MEGA) Software Version 4.0. Mol. Biol. Evol. 24(8): 1596-1599.

57. Tian, F.; Ding, Y.; Zhu, H.; Yao, L.; Du, B. (2009). Genetic diversity of siderophore-producing bacteria of tobacco rhizosphere. Braz. J. Microbiol. 40(2): 276-284.

58. Ulrich, K.; Ulrich, A.; Ewald, D. (2008). Diversity of endophytic bacterial communities in poplar grown under field conditions. FEMS Microbiol. Ecol. 63(2): 169-180.

59. Van Aken, B.; Peres, C.M.; Doty, S.L.; Yoon, J.M.; Schnoor, J.L. (2004). Methylobacterium populi sp. nov., a novel aerobic, pinkpigmented, facultatively methylotrophic, methane-utilizing bacterium isolated from poplar trees (Populus deltoidesxnigra DN34). Int. J. Syst. Evol. Microbiol. 54(4): 1191-1196.

60. Vivas, A.; Biró, B.; Ruíz-Lozano, J.M.; Barea, J.M.; Azcón, R. (2006). Two bacterial strains isolated from a Zn-polluted soil enhance plant growth and mycorrhizal efficiency under Zn-toxicity. Chemosphere 62(9): 1523-1533.

61. Wang, Q.; Garrity, G.M.; Tiedje, J.M.; Cole, J.R. (2007). Naive bayesian classifier for rapid assignment of rRNA sequences into the new bacterial taxonomy. Appl. and Environ. Microbiol. 73(16): 5261-5267.

62. Webster, D.M.; Atkin, J.D.; Cross, J.E. (1983). Bacterial blights of snap beans and their control. Plant Disease 67(10): 935-940.

63. Walker, R.; Powell, A.A; Seddon, B. (1998). Bacillus isolates from the spermosphere of peas and dwarf French beans with antifungal activity against Botrytis cinerea and Pythium species. J. Appl. Microbiol. 84, 791-801. 